\title{
Ocena zgodności z Konstytucją przepisu ustawy o ochronie zabytków i opiece nad zabytkami dotyczącego ujęcia nieruchomości w gminnej ewidencji zabytków ${ }^{1}$
}

\begin{abstract}
Evaluation of conformity to the Constitution of the provision of the Act on the Protection and Care of Historical Monuments concerning the inclusion of a real estate in the communal register of monuments: The evaluated provision of the Act on the Protection and Care of Historical Monuments enables including in the communal register of monuments of a designated real estate without providing the proprietor with a guarantee of protection of his rights against making such an entry. In the draft Sejm's position it was concluded that this provisions does not conform to the Constitution, because of the fact, that it restricts the right of ownership without providing the owner with a guarantee of legal protection against such a restriction. The provisions do not specify, what actions, procedure and form should apply to including a certain real estate in the communal register of monuments.
\end{abstract}

Keywords: Constitutional Tribunal, historical monuments

Słowa kluczowe: Trybunał Konstytucyjny, zabytki

Ekspert ds. legislacji BAS • agnieszka.tomaszewska@sejm.gov.pl • https://orcid.org/0000-0001-9524-8671

Na podstawie art. 69 ust. 2 w związku z art. 42 pkt 3 ustawy z dnia 30 listopada 2016 r. o organizacji i trybie postępowania przed Trybunałem Konstytucyjnym (Dz. U. poz. 2072), w imieniu Sejmu Rzeczypospolitej Polskiej, przedkładam wyjaśnienia w sprawie pytania prawnego Naczelnego Sądu Administracyjnego z 13 czerwca 2018 r. (sygn. akt P 12/18), jednocześnie wnosząc o stwierdzenie,

1 Projekt stanowiska w sprawie pytania prawnego Naczelnego Sądu Administracyjnego z 13 czerwca 2018 r. dot. art. 22 ust. 5 pkt 3 ustawy z dnia 23 lipca 2003 r. o ochronie zabytków i opiece nad zabytkami (t.j. Dz. U. 2018, poz. 2067) w zakresie, w jakim „ogranicza prawo własności nieruchomości poprzez dopuszczenie ujęcia nieruchomości jako zabytku nieruchomego w gminnej ewidencji zabytków, bez zapewnienia właścicielowi gwarancji ochrony prawnej przed dokonaniem takiego ograniczenia" sporządzony 15 lutego 2019 r., sygn. akt P 12/18; BAS-WAKiU 2408/18. 
że art. 22 ust. 5 pkt 3 ustawy z dnia 23 lipca 2003 r. o ochronie zabytków i opiece nad zabytkami (t.j. Dz. U. 2018, poz. 2067) w zakresie, w jakim umożliwia ujęcie w gminnej ewidencji zabytków nieruchomości wyznaczonej bez zapewnienia właścicielowi gwarancji ochrony jego praw przed dokonaniem takiego ujęcia, jest niezgodny z art. 64 ust. 1 i ust. 2 w związku z art. 31 ust. 3 Konstytucji oraz $\mathrm{z}$ art. 1 protokołu nr 1 do Konwencji o ochronie praw człowieka i podstawowych wolności, sporządzonego w Paryżu dnia 20 marca 1952 r. (Dz. U. 1995, Nr 36, poz. 175).

\section{Uzasadnienie}

\section{Przedmiot kontroli}

Naczelny Sąd Administracyjny (dalej: sąd pytający albo NSA) przedmiotem kontroli w niniejszej sprawie uczynił art. 22 ust. 5 pkt 3 ustawy z dnia 23 lipca 2003 r. o ochronie zabytków i opiece nad zabytkami (t.j. Dz. U. 2018, poz. 2067; dalej: u.o.z.o.z.) w zakresie, w jakim „ogranicza prawo własności nieruchomości poprzez dopuszczenie ujęcia nieruchomości jako zabytku nieruchomego w gminnej ewidencji zabytków, bez zapewnienia właścicielowi gwarancji ochrony prawnej przed dokonaniem takiego ograniczenia”.

Zakwestionowany przepis stanowi: „W gminnej ewidencji zabytków powinny być ujęte: [...] inne zabytki nieruchome wyznaczone przez wójta (burmistrza, prezydenta miasta) w porozumieniu z wojewódzkim konserwatorem zabytków”.

\section{Stan faktyczny i prawny sprawy zawisłej przed sądem pytającym}

Treść pytania prawnego pozwala na zrekonstruowanie następującego stanu faktycznego sprawy zawisłej przed NSA.

Zarządzeniem Prezydenta Miasta Szczecina, budynek mieszkalny należący do spółki Neptun Developer Sp. z o.o. z siedzibą w Szczecinie (dalej: spółka) został wyznaczony do ujęcia w gminnej ewidencji zabytków oraz włączenia do Gminnej Ewidencji Zabytków Miasta Szczecina. Na powyższą czynność spółka złożyła skargę do Wojewódzkiego Sądu Administracyjnego w Szczecinie (dalej: WSA), wnosząc o jej uchylenie. W skardze wskazała, że przed włączeniem budynku do gminnej ewidencji zabytków nie przeprowadzono żadnego postępowania, w którym ustalono jego wartość historyczną lub artystyczną. Nie dokonano także oceny aktualnego stanu zachowania. Postanowieniem z 5 września 2016 r. WSA skargę odrzucił, uznając, iż została ona wniesiona $\mathrm{z}$ uchybieniem terminu wynikającego $\mathrm{z}$ art. $52 \$ 3$ ustawy z dnia 30 sierpnia 2002 r. - Prawo o postępowaniu przed sądami administracyjnymi (w brzmieniu obowiązującym w 2016 r.; aktualnie: Dz. U. 2018, poz. 1302, ze zm.; dalej: p.p.s.a.). Naczelny Sąd Administracyjny postanowieniem z 15 grudnia 2016 r. (sygn. akt II OSK 
2700/16) uchylił zaskarżone postanowienie WSA, wskazując na konieczność merytorycznego rozpoznania sprawy. Zdaniem NSA wyznaczenie, na podstawie art. 22 ust. 5 pkt 3 u.o.z.o.z., przez organ gminy obiektu do włączenia do gminnej ewidencji zabytków stanowi sprawę z zakresu administracji publicznej. Po ponownym rozpoznaniu sprawy WSA wyrokiem z 31 maja 2017 r., sygn. akt II SA/ Sz 158/17, oddalił skargę spółki. Uznał, że skoro ani ustawa o ochronie zabytków i opiece nad zabytkami, ani rozporządzenie Ministra Kultury i Dziedzictwa Narodowego z dnia 26 maja 2011 r. w sprawie prowadzenia rejestru zabytków, krajowej, wojewódzkiej i gminnej ewidencji zabytków oraz krajowego wykazu zabytków skradzionych lub wywiezionych za granicę niezgodnie z prawem (Dz.U. $\mathrm{Nr}$ 113, poz. 661; dalej: rozporządzenie MKiDN) nie precyzują, jakie czynności, $\mathrm{w}$ jakim trybie i formie powinny zostać dokonane przy włączaniu danej nieruchomości do gminnej ewidencji zabytków, to czynnością wystarczającą i prawidłową będzie „każdy przejaw aktywności organu w tym zakresie” (w tym także oświadczenie Miejskiego Konserwatora Zabytków potwierdzające, że czynność sprawdzenia została przeprowadzona).

Od powyższego wyroku spółka wniosła skargę kasacyjną, w której zarzuciła m.in. naruszenie art. 22 ust. 5 pkt $3 \mathrm{w}$ związku z art. 3 pkt 1 u.o.z.o.z. poprzez ich błędną wykładnię, a w konsekwencji niewłaściwe zastosowanie polegające na uznaniu, że możliwe było nadanie wymienionemu budynkowi charakteru zabytkowego, pomimo braku istnienia (na dzień włączenia budynku do wykazu zabytków) należycie sporządzonej dokumentacji, na podstawie której można uznać istnienie przedmiotowych cech. W konsekwencji, przyjęcie „rozszerzającej interpretacji wskazanej regulacji ustawowej, umożliwiającej włączanie do gminnej ewidencji zabytków budynków, co do których na dzień ich wpisu nie istniała wymagana przepisami prawa dokumentacja umożliwiająca dokonanie wpisu". Skarżąca zarzuciła także naruszenie art. 21 ust. 1, art. 31 ust. 3 oraz art. 64 ust. 1-3 w związku z art. 2 oraz art. 8 ust. 2 Konstytucji, poprzez brak ich bezpośredniego zastosowania przez WSA.

Rozpatrując niniejszą sprawę, a także biorąc pod uwagę treść zarzutów skargi kasacyjnej, NSA postanowił wystąpić z pytaniem prawnym do Trybunału Konstytucyjnego, uznając, że od odpowiedzi na nie zależy rozstrzygnięcie toczącej się sprawy.

\section{Zarzuty sądu pytającego}

Zdaniem NSA obowiązujące przepisy ustawy o ochronie zabytków umożliwiają dowolne i arbitralne wpisywanie nieruchomości do gminnej ewidencji zabytków, nie zapewniając ich właścicielom stosownych gwarancji, tak materialnych, jak i procesowych. Przepisy nie precyzują, w jaki sposób ma dojść do „sprawdzenia kart adresowych” obiektu włączanego do ewidencji ani też w jaki sposób czynność ta powinna zostać udokumentowana, co powoduje, że każdy przejaw aktywności organu $\mathrm{w}$ tym zakresie uznaje się za wystarczają- 
cy. W takiej sytuacji kontrola sądowoadministracyjna takiej czynności staje się czysto formalna: sąd nie może zweryfikować, czy dany obiekt rzeczywiście jest zabytkiem i czy ograniczenie własności znajduje in casu uzasadnienie. Co więcej, wszystkie te czynności pozostają niejawne dla właściciela nieruchomości, który o dokonanym ograniczeniu dowiaduje się już po fakcie - co w ocenie NSA jest rozwiązaniem nieracjonalnym. Zdaniem pytającego sądu zakwestionowany przepis w sposób nieproporcjonalny ogranicza prawo własności, naruszając art. 64 ust. 1 i ust. 2 w związku z art. 31 ust 3 Konstytucji, jak również gwarancje wynikające $\mathrm{z}$ art. 1 protokołu nr 1 do Konwencji o ochronie praw człowieka i podstawowych wolności, sporządzonego w Paryżu dnia 20 marca 1952 r. (Dz. U. 1995, Nr 36, poz. 175; dalej: protokół nr 1). Jak wskazuje NSA, wątpliwości wzbudza „dopuszczenie ograniczenia prawa własności w ramach uproszczonej procedury, która ma charakter wewnętrzny, a właściciel nie bierze udziału w jakichkolwiek czynnościach postępowania administracyjnego. Przede wszystkim nie są mu znane motywy objęcia nieruchomości ewidencją gminną, tj. czy rzeczywiście nieruchomość stanowi «zabytek»; nie wie również, czy czynności wykonywane w postępowaniu są prawidłowe. Nie bez znaczenia pozostaje także fakt nieformalnego charakteru tych czynności i braku materiału bazowego («dowodów»)".

W ocenie NSA konieczna jest konfrontacja zakwestionowanej regulacji pod kątem jej „niezbędności” dla ochrony interesu publicznego oraz tego „czy efekty wprowadzonej regulacji pozostają w dopuszczalnej proporcji do ciężarów nakładanych na obywatela”. Jak podkreśla, „powstaje pytanie, czy odebranie poszczególnych uprawnień proceduralnych spełnia niektóre z warunków konstytucyjnej dopuszczalności ograniczenia praw i wolności. Najistotniejszym zarzutem pozostaje to, że osłabienie ochrony własności poprzez całkowite «ukrywanie» przed właścicielem informacji o działaniach władzy, skutkujących ograniczeniem własności, nie służy realizacji żadnych konstytucyjnie uzasadnionych wartości”. Ponadto, zdaniem NSA, konieczna jest odpowiedź, „czy art. 22 ust. 5 pkt 3 u.o.z.o.z. jest zgodny z wymaganą przez art. 1 protokołu nr 1 do Konwencji o ochronie praw człowieka i podstawowych wolności właściwą równowagą pomiędzy ograniczeniem a ochroną praw właściciela [...] Wprawdzie co do zasady art. 1 ww. protokołu nie zawiera proceduralnych wymogów ochrony prawa własności, to jednak proceduralne uregulowania, zdaniem Europejskiego Trybunału Praw Człowieka, muszą dawać jednostce racjonalną możliwości rozpoznania jej sprawy przez właściwe organy w celu efektywnej (rzeczywistej) oceny środków ograniczających prawo własności (w szczególności Zehentner v. Austria, no. 20082/02, \$ 73, 16 lipca 2009; wyrok ETPCz z 29 marca 2011 r. w sprawie Potomska i Potomski v. Polska (skarga nr 33949/05)). Powstaje zatem pytanie, czy wynikający z art. 22 ust. 5 pkt 3 u.o.z.o.z. proceduralny mechanizm zapewnia adekwatną ochronę właścicieli przed arbitralnym ujęciem ich nieruchomości w gminnej ewidencji zabytków”. 


\section{Analiza formalnoprawna}

1. Przed przystąpieniem do oceny konstytucyjności przedstawionego przez NSA problemu należy zwrócić uwagę na aspekty formalnoprawne, które mogą stanowić przeszkodę w merytorycznym rozstrzygnięciu sprawy przez Trybunał Konstytucyjny.

Trybunał Konstytucyjny wielokrotnie wyjaśniał warunki dopuszczalności pytania prawnego $\mathrm{w}$ postępowaniu przed sądem konstytucyjnym (postanowienie TK z 11 lutego 2015 r., sygn. akt P 44/13, i przywołane tam orzeczenia). Uwagi zawarte w dotychczasowym orzecznictwie zachowują aktualność również pod rządami obecnie obowiązującej ustawy z dnia 30 listopada 2016 r. o organizacji i trybie postępowania przed Trybunałem Konstytucyjnym (Dz. U. poz. 2072; dalej: ustawa o TK; zamiast wielu zob. wyrok TK z 18 października 2016 r., sygn. akt $P$ 123/15).

W myśl art. 193 Konstytucji każdy sąd może przedstawić Trybunałowi Konstytucyjnemu pytanie prawne co do zgodności aktu normatywnego z Konstytucją, ratyfikowanymi umowami międzynarodowymi lub ustawą, jeżeli od odpowiedzi na to pytanie zależy rozstrzygnięcie sprawy toczącej się przed sądem. W przepisie tym zawarto trzy przesłanki, których łączne spełnienie warunkuje dopuszczalność przedstawienia Trybunałowi Konstytucyjnemu pytania prawnego. Są to: 1) przesłanka podmiotowa, zgodnie z którą pytanie może być przedstawione wyłącznie przez sąd, rozumiany jako państwowy organ władzy sądowniczej, oddzielony i niezależny od legislatywy i egzekutywy; 2) przesłanka przedmiotowa, zgodnie z którą przedmiotem pytania prawnego może być wyłącznie ocena zgodności aktu normatywnego z Konstytucją, ratyfikowanymi umowami międzynarodowymi lub ustawą; 3) przesłanka funkcjonalna, zgodnie z którą wystąpienie z pytaniem prawnym jest uzasadnione tylko wówczas, gdy od odpowiedzi na nie zależy rozstrzygnięcie konkretnej sprawy toczącej się przed sądem (zob. np. postanowienia TK z: 29 marca 2000 r., sygn. akt P 13/99; 10 października 2000 r., sygn. akt P 10/00; 27 kwietnia 2004 r., sygn. akt P 16/03; 6 lutego 2007 r., sygn. akt P 33/06).

2. Jak wynika z uzasadnienia pytania prawnego, zarzuty NSA koncentrują się na braku regulacji, na podstawie której właściciel nieruchomości mógłby podważać jej wpis do gminnej ewidencji zabytków („ogranicza prawo własności nieruchomości poprzez dopuszczenie ujęcia nieruchomości jako zabytku nieruchomego w gminnej ewidencji zabytków, bez zapewnienia właścicielowi gwarancji ochrony tak procesowych, jak i materialnoprawnej przed dokonaniem takiego ograniczenia"). Biorąc pod uwagę sformułowane zastrzeżenia, można uznać, że problem dotyczy braków (deficytów) w zakresie uregulowania zasad i trybu wpisywania zabytków do gminnej ewidencji, polegających m.in. na nieprzyznaniu właścicielowi nieruchomości prawa uczestniczenia w podejmowanych przez organ wyznaczający i wojewódzkiego konserwatora zabytków czynnościach („dopuszczenie ograniczenia prawa własności w ramach uproszczonej procedury, 
która ma charakter wewnętrzny, a właściciel nie bierze udziału w jakichkolwiek czynnościach"). Wydaje się zatem, że NSA nie kwestionuje konstytucyjności regulacji przewidującej ujęcie nieruchomości w gminnej ewidencji zabytków (pozytywnej treści) per se, ale mechanizm, w jakim zostaje dokonane wyznaczenie i ujęcie do tej ewidencji nieruchomości. Naruszenie konstytucyjnych praw, wynika w ocenie NSA, z braku przepisów umożliwiających właścicielowi nieruchomości ich ochronę w ramach "postępowania dotyczącego wpisu do ewidencji”, które de lege lata nie ma charakteru postępowania administracyjnego. Wydaje się zatem, iż oczekiwana przez NSA zmiana wymagałby interwencji ustawodawcy i konieczności przyjęcia nowej regulacji ustawowej, która kompleksowo unormowałaby powyższą materię. Zarzut braku takiej regulacji może być natomiast rozpatrywany w kategoriach zaniechania prawodawczego, którego badanie pozostaje poza zakresem kognicji Trybunału.

Kognicja Trybunału Konstytucyjnego w zakresie kontroli konstytucyjności określona jest w art. 188 pkt 1-3 Konstytucji. Przepis ten nie przewiduje w sposób bezpośredni możliwości kontroli zgodności z Konstytucją aktów normatywnych w zakresie, w jakim nie zawierają one określonej treści normatywnej. De constitutione lata Trybunał Konstytucyjny rozróżnia jednak zaniechanie ustawodawcze od pominięcia ustawodawczego. Zgodnie z utrwaloną linią orzeczniczą sądu konstytucyjnego, „Z zaniechaniem prawodawczym związany jest całkowity brak ingerencji prawodawcy w system prawa wtedy, gdy jest on do tego zobowiązany przez wiążącą go normę prawną. Inaczej jest w przypadku pominięcia: prawodawca tworzy przepisy prawne, dając wyraz temu, że normuje pewną dziedzinę spraw, lecz czyni to z punktu widzenia Konstytucji wadliwie. Jest przy tym obojętne, czy jego aktywność legislacyjna podjęta jest w następstwie wykonania ciążącego na nim obowiązku uregulowania jakichś spraw, czy też uczynił użytek z kompetencji prawodawczej, ponieważ uznał to za celowe" (wyrok TK z 6 listopada 2012 r., sygn. akt K 21/11). Trybunał stoi na stanowisku, że nie ma kognicji do orzekania o zaniechaniach ustawodawczych, natomiast ma kompetencję do orzekania o tzw. pominięciach prawodawczych.

Z kolei „pominięcie prawodawcze zachodzi niespornie wtedy, gdy prawodawca w wydanym przez siebie akcie normatywnym przewidział jakąś czynność konwencjonalną, lecz pominął reguły jej dokonywania - wszystkie lub tylko niektóre - w następstwie czego czynności konwencjonalnej «ważnie» dokonać się nie da. Jest to typowa sytuacja określana mianem luki tetycznej (konstrukcyjnej): prawodawca w akcie normatywnym daje wyraz woli wykreowania określonej czynności konwencjonalnej, ale czyni to konstrukcyjnie wadliwie" (zob. wyrok TK z 6 listopada 2012 r., sygn. akt sygn. akt K 21/11). Przez pominięcie prawodawcze Trybunał rozumie również „sytuacje, gdy prawodawca w akcie normatywnym kształtuje jakąś sytuację prawną, na którą zazwyczaj składają się powiązane ze sobą funkcjonalnie kompetencje, obowiązki, uprawnienia jakiegoś podmiotu, przy czym: 1) nie stanowi norm, które są niezbędne, by wyzna- 
czone obowiązki dało się zrealizować, lub norm, które umożliwiałyby czynienie użytku z przyznanych kompetencji lub uprawnień bądź też 2) nie przewiduje odpowiednich gwarancji zabezpieczających egzekwowanie albo kontrolę wykonywania rozważanych obowiązków, kompetencji czy uprawnień. W tego rodzaju przypadkach Trybunał Konstytucyjny stwierdza brak normy lub norm, które umożliwiałyby funkcjonowanie mechanizmu przyjętego przez prawodawcę" (zob. wyrok TK z 6 listopada 2012 r., sygn. akt K 21/11). Ponadto „Trybunał [...] musi podchodzić z ostrożnością do zarzutów odnoszących się do istnienia luki normatywnej, aby działalnością orzeczniczą nie wkraczać w sferę tworzenia prawa, zastrzeżoną dla władzy ustawodawczej. Możliwość oceny konstytucyjności pominięć prawodawczych podlega regule excepciones non sunt extendendae" (postanowienie TK z 25 listopada 2015 r., sygn. akt Ts 248/13).

W nauce prawa podkreśla się brak wyraźnych kryteriów, według których można odróżniać zaniechanie od pominięcia (zob. P. Tuleja, Zaniechanie ustawodawcze [w:] Ustroje, doktryny, instytucje polityczne. Ksiegga jubileuszowa Profesora $z$ w. dra hab. Mariana Grzybowskiego, red. J. Czajowski, Kraków 2007, s. 398, 403404). Niemniej dostrzega się ścisły związek między dopuszczalnością orzekania o tzw. pominięciach ustawodawczych a obowiązkiem państwa zapewnienia realizacji konstytucyjnych praw i wolności (ibidem, s. 401 i n.). „Podsumowując swoje orzecznictwo w zakresie pominięć prawodawczych, Trybunał stwierdził m.in., że pominięcia te są związane na ogół z niezapewnieniem właściwej realizacji konstytucyjnych wolności lub praw przysługujących danej kategorii podmiotów. Największa grupa wyroków w sprawie pominięcia ustawodawczego dotyczy bowiem właśnie nieprzyznania pewnych praw określonej kategorii podmiotów" (wyrok TK z 6 listopada 2012 r., sygn. akt K 21/11, zob. też wyroki TK z: 28 kwietnia 2009 r., sygn. akt K 27/07; 16 czerwca 2009 r., sygn. akt SK 5/09). Ponieważ granica między zaniechaniem a pomięciem prawodawczym nie jest jednoznaczna i w praktyce jej określenie może budzić wątpliwości, w orzecznictwie TK wypracowano kryteria pomocne w odróżnieniu tych przypadków. Jednym z nich jest ratio legis kwestionowanego przepisu, które może wskazać, czy zarzucany brak określonej regulacji nie stanowi zamierzonego działania ustawodawcy, chcącego pozostawić określone zagadnienie poza regulacją prawną (zob. postanowienie TK z 14 stycznia 2015 r., sygn. akt P 9/14, wraz z przytoczonym tam orzecznictwem oraz piśmiennictwem; postanowienie TK z 7 listopada 2018 r., sygn. akt $\mathrm{P}$ 6/17).

3. Odnosząc powyższe do analizowanej sprawy, należy zaznaczyć, że NSA nie wskazał wyraźnie normy, której zakres zastosowania został przez ustawodawcę ujęty zbyt wąsko w stosunku do obowiązku wynikającego z określonych przepisów Konstytucji. Na podstawie zaskarżonych przepisów można natomiast skonstruować normę kompetencyjną, która dotyczy możliwości wpisania zabytku nieruchomego do gminnej ewidencji zabytków na podstawie porozumienia między organem gminy a wojewódzkim konserwatorem zabytków (art. 22 ust. 5 
u.o.z.o.z.) i określa stricte formalne przesłanki takiego wpisu odnoszące się do treści karty adresowej zabytku nieruchomego ( $\$ 18$ rozporządzenia MKiDN).

W razie uznania, że NSA nie domaga się poszerzenia zakresu regulacji i zastosowania tej normy (tj. objęcia nią sytuacji w niej nieuregulowanych, które ze względu na określoną normę konstytucyjną, powinny zostać objęte jej zakresem), ale postuluje wprowadzenie zupełnie nowej - o charakterze proceduralnym (dotyczącej zasad uczestniczenia właściciela nieruchomości w podejmowanych czynnościach zmierzających do ujęcia tej nieruchomości w gminnej ewidencji zabytku), to w ocenie Sejmu tak sformułowany zarzut miałby charakter skargi na lukę prawną - co uniemożliwiałoby merytoryczne rozpoznanie sprawy. Mając na uwadze aktualny charakter ewidencji (zbliżony do charakteru rejestru zabytków), można jedynie antycypować, że postulowana regulacja powinna mieć kształt zbliżony do art. 9 u.o.z.o.z. [przykładowo stanowić, że wpis do tej ewidencji następuje na podstawie zaskarżalnej decyzji administracyjnej wydanej w wyniku postępowania administracyjnego, w którym właściciel (użytkownik wieczysty) nieruchomości mógłby uczestniczyć na prawach strony]. Wobec powyższego, zasadne byłoby wniesienie o umorzenie postępowania przed Trybunałem Konstytucyjnym w niniejszej sprawie ze względu na niedopuszczalność wydania wyroku (art. 59 ust. 1 pkt 2 ustawy o TK).

Przyjęcie natomiast, że mamy do czynienia z sytuacją, w której ustawodawca unormował omawianą dziedzinę, ale dokonał tego w sposób niepełny z perspektywy norm konstytucyjnych, umożliwia kontrolę wskazanej normy. Stwierdzenie przez Trybunał Konstytucyjny pominięcia prawodawczego związane było na ogół z niezapewnieniem właściwej realizacji konkretnych praw lub wolności przysługujących danej kategorii podmiotów. Największa grupa wyroków dotyczących pominięcia dotyczy nieprzyznania pewnych praw określonej kategorii podmiotów (zob. przykładowo wyroki TK z: 16 czerwca 2009 r., sygn. akt SK 5/09; 28 kwietnia 2009 r., sygn. akt K 27/07). Kontrola konstytucyjności pominięć prawodawczych, rozumianych jako braki w istniejących już regulacjach prawnych, jakkolwiek dopuszczalna, nie może dotyczyć braków każdego rodzaju, ale tylko takich, które powodują niezapewnienie należytego stopnia realizacji konkretnych praw i wolności przysługujących danej kategorii podmiotów (zob. postanowienie TK z 29 listopada 2010 r., sygn. akt P 45/09). Powyższe zakłada przyjęcie, że w określonym przypadku zachodzi jakościowa tożsamość materii unormowanych w danym przepisie i tych pozostawionych poza jego zakresem. Konsekwentnie należy wówczas uznać, że we wskazanych przez NSA przepisach odnaleźć można szczątkowe „procedury”, a także to, że niepełność i fragmentaryczność regulacji nie jest intencjonalnym i uzasadnionym działaniem ustawodawcy.

Sygnalizując w ramach analizy formalnoprawnej powyższe wątpliwości, Sejm poddaje pod rozwage Trybunału Konstytucyjnego ocenę znaczenia poczynionych zastrzeżeń z punktu widzenia dopuszczalności wydania merytorycznego rozstrzygnięcia w niniejszej sprawie. 
4. Informacyjnie warto przywołać postanowienie Trybunału Konstytucyjnego z 7 listopada 2016 r., sygn. akt SK 3/15, w którym przedmiotem skargi konstytucyjnej był art. 22 ust. 5 pkt 3 u.o.z.o.z. (a także $\$ 18$ rozporządzenia MKiDN). Jak wówczas wskazał Trybunał: „Z petitum skargi konstytucyjnej, jak i jej uzasadnienia wynika jednoznacznie, że skarżąca spółka nie kwestionuje treści normatywnej zaskarżonych przepisów, ale ich «niekompletność» z punktu widzenia ochrony praw właściciela nieruchomości podlegającej wpisowi do gminnej ewidencji zabytków. W przekonaniu skarżącej spółki, zaskarżone przepisy są niekonstytucyjne, ponieważ nie gwarantują ochrony prawa własności i innych praw majątkowych w ramach sprawiedliwej procedury przed organami władzy publicznej, a przede wszystkim pozbawiają osoby uprawnione realnej możliwości udziału w merytorycznym postępowaniu administracyjnym zmierzającym do wpisania nieruchomości do gminnej ewidencji zabytków oraz nie zapewniają poinformowania przez organ administracji o czynności sporządzenia karty adresowej zabytku nieruchomego oraz o włączeniu tej karty do gminnej ewidencji zabytków. Nie ulega więc wątpliwości, co podkreśla też RPO w piśmie procesowym, że zarzuty niekonstytucyjności sformułowane w skardze konstytucyjnej dotyczą braku regulacji, bez której zaskarżone przepisy - w przekonaniu skarżącej spółki - naruszają wskazane wzorce konstytucyjne. Mamy więc do czynienia z zakwestionowaniem konstytucyjności tego, czego ustawodawca nie uregulował, choć w przekonaniu skarżącej spółki powinien był to uczynić. Trybunał Konstytucyjny rozróżnia w tym względzie zaniechanie prawodawcze od pominięcia, uznając, że jedynie pominięcie może podlegać ocenie konstytucyjności (zob. wyrok TK o sygn. SK 22/13)”. Trybunał wskazał jednocześnie: „Nie ulega bowiem wątpliwości, że ochrona prawa własności i innych praw majątkowych pojmowanych podmiotowo gwarantowana jest przede wszystkim w art. 64 ust. 1 i 2 Konstytucji. Stąd też prawa do ochrony własności i innych praw majątkowych, na które wskazuje skarżąca spółka, można poszukiwać w art. 64 ust. 1 i 2 Konstytucji, a nie w art. 64 ust. 3 Konstytucji. Nie sposób bowiem uznać art. 64 ust. 3 Konstytucji za właściwy wzorzec kontroli, jeśli zarzut nie dotyczy ograniczenia własności czy też naruszenia jej istoty. Tym bardziej, że skarżąca spółka nie kwestionuje samej ingerencji w prawo własności nieruchomości poprzez możliwość wpisania jej do gminnego rejestru zabytków, ale brak należytych gwarancji o charakterze procesowym - «wyłączenie prawa do ochrony własności i innych praw majątkowych w ramach sprawiedliwej procedury przed organami władzy publicznej»".

W ocenie Trybunału skarżąca spółka w sprawie o sygn. akt SK 3/15, kwestionując postępowanie dotyczące wpisu nieruchomości do gminnej ewidencji zabytków, nie wskazała prawidłowych, z punktu widzenia sformułowanego zarzutu niekonstytucyjności, wzorców kontroli. Jak stwierdził wówczas Trybunał „nie sposób więc uznać, że skarżąca spółka sformułowała należycie (poprawnie) zarzut naruszenia przez art. 22 ust. 5 pkt 3 ustawy o ochronie zabytków oraz $\$ 18$ 
rozporządzenia art. 45 ust. 1 Konstytucji, ani tym bardziej, że zarzut ten został uzasadniony z powołaniem dowodów na jego poparcie”. W konsekwencji, postanowił umorzyć postępowanie ze względu na niedopuszczalność merytorycznego rozpoznania zarzutów (wydania wyroku).

\section{Analiza zgodności}

\section{- 1. Wzorce kontroli}

1. Przepisy art. 64 ust. 1 i ust. 2 Konstytucji stanowią odpowiednio: „Każdy ma prawo do własności, innych praw majątkowych oraz prawo dziedziczenia” oraz: „Własność, inne prawa majątkowe oraz prawo dziedziczenia podlegają równej dla wszystkich ochronie prawnej”.

W orzecznictwie Trybunału Konstytucyjnego powstałym na tle przywołanych przepisów ugruntowany jest pogląd, że „na ustawodawcy pozytywnym spoczywa nie tylko obowiązek pozytywny stanowienia przepisów i procedur udzielających ochrony prawnej prawom majątkowym, ale także obowiązek negatywny powstrzymania się od przyjmowania regulacji, które owo prawo mogłyby pozbawiać ochrony prawnej lub też ochronę tę ograniczać" (zob. wyroki TK z: 13 kwietnia 1999 r., sygn. akt K 36/98; 29 czerwca 2004 r., sygn. akt P 20/02; 21 grudnia 2005 r., sygn. akt SK 10/05; 20 kwietnia 2009 r., sygn. akt SK 55/08). Sprzeczne ze standardem konstytucyjnym są w szczególności rozwiązania normatywne, których skutkiem jest „wydrążenie” konkretnego prawa podmiotowego z uprawnień składających się na jego istotę albo takich, które tworzą pozorne i nieefektywne mechanizmy ochrony praw podmiotowych (zob. wyrok TK z 1 września 2006 r., sygn. akt SK 14/05).

Ochrona zapewniana własności i innym majątkowym prawom podmiotowym, zgodnie z art. 64 ust. 1 (a także art. 21 ust. 1 Konstytucji), musi być realna. Kryterium weryfikacji tej cechy jest skuteczność realizacji określonego prawa podmiotowego w konkretnym otoczeniu systemowym, w którym ono funkcjonuje (zob. orzeczenia powołane powyżej oraz wyroki TK z: 25 lutego 1999 r., sygn. akt K 23/98; 12 stycznia 2000 r., sygn. akt P 11/98; 19 grudnia 2002 r., sygn. akt K 33/02; 20 stycznia 2004 r., sygn. akt SK 26/03). Z drugiej strony Trybunał Konstytucyjny podkreśla, że ochrona własności i innych praw majątkowych nie ma charakteru absolutnego, a jej ograniczenia są dopuszczalne z zachowaniem warunków przewidzianych w art. 31 ust. 3 oraz art. 64 ust. 2 i ust. 3 Konstytucji, tj. na podstawie ustawy i z poszanowaniem zasad równości oraz proporcjonalności.

2. W myśl art. 31 ust. 3 Konstytucji: „Ograniczenia w zakresie korzystania z konstytucyjnych wolności i praw mogą być ustanawiane tylko w ustawie i tylko wtedy, gdy są konieczne w demokratycznym państwie dla jego bezpieczeństwa lub porządku publicznego, bądź dla ochrony środowiska, zdrowia i moralności publicznej, albo wolności i praw innych osób. Ograniczenia te nie mogą naruszać istoty wolności i praw". 
Analiza orzecznictwa Trybunału Konstytucyjnego wskazuje, że zasada proporcjonalności określa dopuszczalny zakres ograniczeń korzystania z konstytucyjnych praw i wolności, wymagając ustalenia, czy kwestionowana norma spełnia trzy wymagania: przydatności, konieczności i proporcjonalności w ścisłym znaczeniu tego słowa. Ustanowione ograniczenia spełniają wymóg proporcjonalności, jeżeli wprowadzona regulacja ustawodawcza jest w stanie doprowadzić do zamierzonych przez nią skutków (zasada przydatności), jest niezbędna dla ochrony interesu publicznego, z którym jest powiązana (zasada konieczności), a jej efekty pozostają w proporcji do ciężarów nakładanych przez nią na obywatela (zasada proporcjonalności w znaczeniu ścisłym; zob. wyroki TK z: 11 kwietnia 2006 r., sygn. akt SK 57/04; 11 kwietnia 2000 r., sygn. akt K 15/98). Przesłanka proporcjonalności sensu stricto oznacza dla ustawodawcy obowiązek wyboru najmniej dolegliwego środka realizacji określonego interesu (wartości) podlegającego konstytucyjnej ochronie. Ocena, czy przesłanki te zostały spełnione, wymaga zatem w każdym konkretnym przypadku skonfrontowania wartości i dóbr chronionych daną regulacją z tymi, które w jej efekcie podlegają ograniczeniu. Przepis wprowadzający ograniczenie jest niezgodny z Konstytucją, jeżeli te same efekty można osiągnąć za pomocą środków, które w mniejszym zakresie ograniczają korzystanie z wolności lub prawa podmiotowego. Trybunał Konstytucyjny podkreśla, że istotą tak rozumianego nakazu nadmiernej ingerencji jest uznanie, że ustawodawca nie może ustanawiać ograniczeń przekraczających pewien stopień uciążliwości, a zwłaszcza zapoznających proporcję pomiędzy stopniem naruszenia uprawnień jednostki a rangą interesu publicznego, który ma w ten sposób podlegać ochronie (zob. orzeczenie TK z 26 kwietnia 1995 r., sygn. akt K 11/94; wyroki TK z: 22 lutego 2005 r., sygn. akt K 10/04; 28 czerwca 2000 r., sygn. akt K 34/99).

Co do zasady, naruszenie art. 31 ust. 3 Konstytucji może mieć miejsce w sytuacji, w której da się w pierwszej kolejności stwierdzić, że w ogóle doszło do ingerencji w proklamowane w innych przepisach ustawy zasadniczej wolności lub prawa człowieka i obywatela. Zdaniem Trybunału wspomniany przepis nie formułuje bowiem samoistnego prawa o randze konstytucyjnej i zawsze musi być stosowany z innymi normami ustawy zasadniczej, musi zostać powiązany z konkretnym prawem podmiotowym (zob. wyroki TK z: 29 kwietnia 2003 r., sygn. akt SK 24/02; 19 stycznia 2010 r., sygn. akt SK 35/08; 12 lipca 2011 r., sygn. akt SK 49/08; postanowienia TK z: 17 grudnia 2009 r., sygn. akt U 6/08; 29 grudnia 2009 r., sygn. akt Ts 393/08). W niektórych judykatach, nawiązując do art. 2 Konstytucji, Trybunał Konstytucyjny uznaje jednak, że zasada proporcjonalności ma znaczenie szersze, odnosi się bowiem do ogółu sytuacji, w których państwo za pomocą stanowionego przez siebie prawa oddziałuje na pozycję osoby pozostającej pod jego władzą. W takich wypadkach zarzut braku proporcjonalności jest oceniany bez nawiązania do wkroczenia w podmiotowe prawo konstytucyjne (oczywiście, jeżeli nie wpływa to na dopuszczalność zainicjowania kontroli konstytucyjności określaną na podstawie art. 79 ust. 1 Konstytucji; zob. przykłado- 
wo wyroki TK z: 27 maja 2002 r., sygn. akt K 20/01; 13 marca 2007 r., sygn. akt K 8/07; 24 listopada 2008 r., sygn. akt K 66/07).

3. Z kolei zgodnie z art. 1 protokołu: „Każda osoba fizyczna i prawna ma prawo do poszanowania swego mienia. Nikt nie może być pozbawiony swojej własności, chyba że w interesie publicznym i na warunkach przewidzianych przez ustawę oraz zgodnie z ogólnymi zasadami prawa międzynarodowego. Powyższe postanowienia nie będą jednak w żaden sposób naruszać prawa państwa do stosowania takich ustaw, jakie uzna za konieczne do uregulowania sposobu korzystania $\mathrm{z}$ własności zgodnie z interesem powszechnym lub w celu zabezpieczenia uiszczania podatków bądź innych należności lub kar pieniężnych”.

W doktrynie i orzecznictwie Europejskiego Trybunału Praw Człowieka (ETPC) przyjmuje się, że przytoczona regulacja w istocie gwarantuje i udziela ochrony prawu własności w szerokim znaczeniu, bo obejmującym nie tylko własność przedmiotów materialnych, ale również różnorakie prawa, interesy, czy też roszczenia o charakterze majątkowym (szeroko na ten temat - zob. A. Wróbel [w:] Konwencja o ochronie praw człowieka i podstawowych wolności. Komentarz do artykułów 19-59 oraz protokołów dodatkowych, t. II, red. L. Garlicki, Warszawa 2011, komentarz do art. 1 protokołu nr 1 do Konwencji o ochronie praw człowieka i podstawowych wolności, nb. 2-5, wraz z przywołaną tam literaturą i orzecznictwem).

Zgodnie ze stanowiskiem ETPC art. 1 protokołu zawiera trzy oddzielne zasady: zasadę poszanowania własności, dopuszczalności pozbawiania własności oraz dopuszczalności kontroli korzystania z własności. „Zasada pierwsza, zawarta w zdaniu pierwszym pierwszego akapitu, ma charakter generalny i gwarantuje poszanowanie mienia; druga zasada, zawarta w drugim zdaniu pierwszego akapitu, mówi o możliwości pozbawienia mienia, ale pod pewnymi warunkami; trzecia zasada, zawarta w drugim akapicie stanowi, że Państwa Strony są uprawnione, m.in. do uregulowania sposobu korzystania $\mathrm{z}$ mienia zgodnie $\mathrm{z}$ interesem powszechnym [...] Te trzy zasady nie są jednakże «odrębne» w tym sensie, że nie ma pomiędzy nimi związku. Zasady drugą i trzecią dotyczące konkretnych sposobów ingerencji w prawo do poszanowania mienia, należy interpretować w świetle ogólnego charakteru zasady pierwszej" (wyroki ETPC z: 23 września 1982 r., sprawa Sporrong i Lönroth vs Szwecja, skargi nr 7151/75 i 7152/75, oraz 30 maja 2000 r., sprawa Belvedere Alberghiera S.r.l. vs Włochy, skarga nr 31524/96).

W wyniku dokonania wykładni językowej art. 1 zdanie trzecie protokołu nr 1 , wyrażającego, że państwo ma prawo do „stosowania takich ustaw, jakie uzna za konieczne do uregulowania sposobu korzystania z własności zgodnie z interesem powszechnym lub w celu zabezpieczenia uiszczania podatków bądź innych należności lub kar pieniężnych" ETPC sformułował trzy zasady, na których opiera się dopuszczalność ograniczeń prawa własności. Pierwsza z nich to zasada legalności, druga sformułowana jako postulat poszukiwania uzasadnionego prawnie celu ograniczenia własności dokonywanej w interesie publicznym i trzecia okre- 
ślana jako zasada sprawiedliwej równowagi (fair balance). Zasada sprawiedliwej równowagi odnosi się do równowagi między interesami powszechnego ogółu a wymaganiami ochrony podstawowych praw jednostki. Troska o zachowanie tej równowagi jest wyrażona w przepisie art. 1 protokołu nr 1 jako całości. Równowaga ta zakłada, że musi istnieć rozsądny stosunek proporcjonalności między środkami zastosowanymi przez państwo, w tym środkami pozbawiającymi osobę własności, a celem, który ma być osiągnięty za ich pomocą. Powołany przepis wyraża implicite adresowany do sądu postulat każdorazowej oceny, czy z powodu działania lub braku działania państwa zainteresowana osoba musiała znosić nieproporcjonalne lub nadmierne obciążenia (wyrok ETPC z 22 czerwca 2004 r., w sprawie Broniowski vs Polska, skarga nr 31443/96).

\section{- 2. Analiza merytoryczna}

1. Ustawą z dnia 18 marca 2010 r. o zmianie ustawy o ochronie zabytków i opiece nad zabytkami oraz o zmianie niektórych innych ustaw (Dz. U. Nr 75, poz. 474; dalej: nowelizacja z 2010 r.) znowelizowano ustawę o ochronie zabytków i opieki nad zabytkami, zmieniając znaczenie gminnej ewidencji zabytków. Przed wejściem w życie nowelizacji z 2010 r. gminna ewidencja zabytków była prowadzona dla celów wewnętrznych i miała charakter systematyzujący, stanowiąc podstawę do sporządzania gminnych programów opieki nad zabytkami (A. Ginter, A. Michalak, Komentarz do art. 7 [w:] Ustawa o ochronie zabytków i opiece nad zabytkami. Komentarz, 2016, LEX nr 500561). W szczególności nie kształtowała sytuacji prawnej podmiotów i nie stanowiła podstawy do zastosowania względem objętego nią obiektu działań o charakterze władczym. Po wprowadzonych zmianach znaczenie gminnej ewidencji zabytków i jej wpływ na sytuację prawną właścicieli ujętych w niej zabytków nieruchomych wzrosły.

Zmiany te oznaczały m.in. wprowadzenie obowiązków polegających na:

- uwzględnieniu ochrony zabytków nieruchomych, znajdujących się w ewidencji, m.in. w decyzji o ustaleniu lokalizacji inwestycji celu publicznego, decyzji o warunkach zabudowy, decyzji o zezwoleniu na realizację inwestycji drogowej, decyzji o ustaleniu lokalizacji linii kolejowej lub decyzji o zezwoleniu na realizację inwestycji w zakresie lotniska użytku publicznego (art. 19 ust. 1a pkt 2 u.o.z.o.z.),

- uzgodnieniu decyzji o warunkach zabudowy przed jej wydaniem z wojewódzkim konserwatorem zabytków w odniesieniu do zabytków ujętych w gminnej ewidencji zabytków (zob. art. 53 ust. 4 pkt 2 ustawy z dnia 27 marca 2003 r. o planowaniu i zagospodarowaniu przestrzennym, t.j. Dz. U. 2018, poz. 1945; dalej: u.p.z.p.).

- uzgodnieniu z wojewódzkim konserwatorem zabytków na etapie postępowania o wydanie pozwolenia na budowę lub rozbiórkę obiektu budowlanego, ujętych w gminnej ewidencji zabytków (zob. art. 39 ust. 3 ustawy z dnia 7 lipca 1994 r. - Prawo budowlane, t.j. Dz. U. 2018, poz. 1202, ze zm.). 
W efekcie wejścia w życie nowelizacji z 2010 r. nastąpiła zmiana dotychczasowego (porządkująco-inwentaryzacyjnego) charakteru ewidencji. Na skutek dokonania wpisu nieruchomości do gminnej ewidencji zabytków korzystanie z przysługującego prawa do nieruchomości zostaje znacznie ograniczone (przykładowo konieczne jest uzyskanie zgody wojewódzkiego konserwatora zabytków na planowaną zmianę przeznaczenia planistycznego nieruchomości oraz na prowadzenie tych prac budowlanych, dla których konieczne jest uzyskanie akceptacji władz budowlanych).

Również w orzecznictwie sądowoadministracyjnym nowelizację z $2010 \mathrm{r}$. oceniono jako istotną zmianę stanu prawnego, nadającą gminnej ewidencji zabytków zupełnie inny status - specyficznej formy ochrony konserwatorskiej (zob. m.in. wyrok NSA z 30 września 2010 r., sygn. akt II OSK 1435/09). De lege lata nie ma wątpliwości, że „wpisy uskutecznione w gminnej ewidencji zabytków prowadzą do ograniczenia uprawnień właścicielskich" (wyroki WSA w Warszawie z: 3 lipca 2013 r., sygn. akt VII SA/Wa 2652/12 i VII SA/Wa 2652/13; 22 maja 2014 r., sygn. akt IV SA/Wa 590/14) i są równoznaczne z „władczym wkroczeniem $\mathrm{w}$ uprawnienia właściciela co do sposobu korzystania z przysługującego mu prawa własności" (wyrok WSA w Łodzi z 18 grudnia 2014 r., sygn. akt II SA/Łd 638/14).

2. W konsekwencji wprowadzonych zmian gminna ewidencja zabytków zyskała status nienazwanej (niewymienionej w art. 7 u.o.z.o.z.) prawnej formy ochrony zabytków. Zgodnie bowiem z art. 7 u.o.z.o.z. ustawowymi formami ochrony zabytków są:

- wpis do rejestru zabytków (pkt 1),

- wpis na Listę Skarbów Dziedzictwa (pkt 1a),

- uznanie za pomnik historii (pkt 2),

- utworzenie parku kulturowego (pkt 3),

- ustalenia ochrony w miejscowym planie zagospodarowania przestrzennego albo w decyzji o ustaleniu lokalizacji inwestycji celu publicznego, decyzji o warunkach zabudowy, decyzji o zezwoleniu na realizację inwestycji drogowej, decyzji o ustaleniu lokalizacji linii kolejowej lub decyzji o zezwoleniu na realizację inwestycji w zakresie lotniska użytku publicznego (pkt 4).

Przepis art. 15 ust. 4 u.o.z.o.z. wskazuje dodatkowy instrument ochrony zabytków, jakim jest wpis pomnika historii na listę dziedzictwa światowego procedura ta odbywa się jednak na podstawie przepisów Konwencji w sprawie ochrony światowego dziedzictwa kulturalnego i naturalnego, przyjętej w Paryżu dnia 16 listopada 1972 r. (Dz. U. 1976, Nr 32, poz. 190).

Co istotne, przewidziane przez ustawodawcę sformalizowane instrumenty ochrony zabytków wymienione w art. 7 u.o.z.o.z. przewidują stosowanie odpowiednich procedur. Objęcie zabytku ochroną - przez zastosowanie jednej z form wymienionych w tym przepisie - jest możliwe po spełnieniu określonych prze- 
słanek ustawowych (warunkiem sine qua non jest uznanie danego obiektu za „zabytek" w rozumieniu art. 3 pkt 1 u.o.z.o.z.) i w ściśle określonym trybie.

I tak, zgodnie $\mathrm{z}$ art. 9 u.o.z.o.z. wpis do rejestru zabytków następuje na podstawie decyzji administracyjnej wydanej przez wojewódzkiego konserwatora zabytków. Taka decyzja musi spełniać warunki określone w art. $107 \$ 1$ i 2 ustawy z dnia 14 czerwca 1960 r. - Kodeks postępowania administracyjnego (t.j. Dz. U. 2018, poz. 2096, ze zm.; dalej: k.p.a.). Jej wydanie poprzedza przeprowadzone postępowanie administracyjne, $\mathrm{w}$ trakcie którego gromadzony jest materiał dowodowy mający istotne znaczenie dla sprawy (dokumentacje i opracowania, materiały archiwalne, wyniki badań, opinie, ekspertyzy, oględziny zabytkowej nieruchomości itp.). Jak wskazuje NSA: „Elementarnym wymogiem do podjęcia decyzji o wpisie do rejestru zabytków założenia urbanistycznego czy poszczególnych obiektów jak również ustalenia granic otoczenia zabytku wpisanego do rejestru jest jednoznaczne wskazanie motywów jakimi kierował się organ, bowiem wpis do rejestru zabytków stanowi wyjątkowo rygorystyczną formę ochrony zabytków i z tego właśnie powodu dużo silniej wkracza i ogranicza prawo własności. Jest to jedna z form ograniczenia prawa własności o jakiej mowa w art. 64 ust. 3 Konstytucji Rzeczypospolitej Polskiej, która gwarantuje obywatelom ochronę własności, a ta może być ograniczona tylko ustawą. Tą ustawą jest w tym wypadku ustawa z 2003 r. o ochronie zabytków" (wyrok NSA z 18 września 2014 r., sygn. akt II OSK 629/13). Postępowanie o wpis wszczyna się z urzędu (inicjatorem jest wojewódzki konserwator zabytków) albo na wniosek strony (właściciel lub użytkownik wieczysty gruntu, na którym znajduje się zabytek nieruchomy). Prawo zgłoszenia żądania wpisania obiektu do rejestru zabytków z urzędu przez wojewódzkiego konserwatora zabytków mają również stowarzyszenia i organizacje społeczne, których jednym z zadań statutowych jest ochrona dziedzictwa kultury (zob. art. $31 \$ 2$ i 4 k.p.a.). Przepis art. 9 ust. 1 u.o.z.o.z. w sposób enumeratywny wymienia podmioty, które mogą zainicjować postępowanie w tej sprawie. Przepis ten nie wyklucza natomiast udziału w tym postępowaniu innego podmiotu, który wykaże posiadanie interesu prawnego (wyrok NSA z 16 czerwca 2011 r., sygn. akt II OSK 1566/10; wyrok WSA w Warszawie z 4 grudnia 2008 r., sygn. akt I SA/Wa 940/08, LEX nr 569610). Tym samym osoba niemająca tytułu prawnego do gruntu nie może skutecznie wystąpić $\mathrm{z}$ wnioskiem o wpis nieruchomości do rejestru zabytków (wyrok WSA w Warszawie z 7 kwietnia 2009 r., sygn. akt I SA/Wa 93/09). O wszczęciu postępowania $\mathrm{z}$ urzędu zawiadamia się każdą ze stron, która ma prawo do uczestniczenia w każdym etapie prowadzonego postępowania administracyjnego oraz do wnoszenia uwag, wniosków i zastrzeżeń. W sytuacji, kiedy nie można ustalić kręgu podmiotów, które powinny wziąć udział w postępowaniu, zastosowanie mają regulacje dotyczące publicznego obwieszczenia (zob. art. 49 k.p.a.). Wydanie stosownej decyzji administracyjnej (art. 104 k.p.a.) kończy postępowanie o wpis do rejestru zabytków. Zgodnie z art. 127 k.p.a. od decyzji tej służy stro- 
nie odwołanie do organu drugiej instancji, w terminie 14 dni od jej doręczenia. Po upływie tego terminu decyzja staje się ostateczna, a organ, który ją wydał, składa wniosek do właściwego sądu rejonowego o ujawnienie wpisu w księdze wieczystej oraz o ogłoszenie tej informacji w dzienniku urzędowym właściwego województwa. Decyzja ma charakter konstytutywny, a wpisanie nieruchomości do rejestru zabytków pociąga za sobą skutki w stosunku do jego właściciela czy też posiadacza i użytkownika, m.in. w postaci ograniczenia uprawnień właścicielskich dysponenta takiego obiektu (np. obowiązkiem uzyskiwania pozwoleń, o których mowa w art. 36 u.o.z.o.z.). Jest zatem bezsporne, że wpis do rejestru zabytków ogranicza niezależność właścicieli lub posiadaczy zabytków w wielu kwestiach. Co jednak istotne - w odróżnieniu od wpisu do gminnej ewidencji zabytków - ustawodawca przewidział odpowiednią „procedurę wpisu”, gwarantującą ochronę praw zainteresowanych podmiotów.

Zgodnie z art. 14a u.o.z.o.z. na Listę Skarbów Dziedzictwa wpisuje się zabytek ruchomy o szczególnej wartości dla dziedzictwa kulturowego zaliczany do jednej z wymienionych w tym przepisie kategorii (m.in.: zabytków archeologicznych, które mają więcej niż 100 lat, wchodzą w skład zbiorów archeologicznych lub zostały pozyskane w wyniku badań archeologicznych lub przypadkowych odkryć, elementów stanowiących integralną część zabytków architektury, wystroju wnętrz, pomników, posągów i dzieł rzemiosła artystycznego, które mają więcej niż 100 lat, map drukowanych, które mają więcej niż 200 lat). Wpis następuje na podstawie decyzji administracyjnej wydanej przez ministra właściwego do spraw kultury i ochrony dziedzictwa narodowego, z urzędu albo na wniosek właściciela zabytku ruchomego.

Z kolei zgodnie $\mathrm{z}$ art. 15 u.o.z.o.z. na wniosek ministra właściwego do spraw kultury i ochrony dziedzictwa narodowego (po uzyskaniu opinii Rady Ochrony Zabytków) Prezydent RP, w drodze rozporządzenia, może uznać za pomnik historii zabytek nieruchomy wpisany do rejestru lub park kulturowy o szczególnej wartości dla kultury, określając jego granice. Przepis ten określa zatem tryb uznania (także cofnięcia uznania) zabytku nieruchomego za pomnik kultury. Co istotne, za taki może zostać uznany wyłącznie obiekt podlegający już ochronie bądź jako zabytek wpisany wcześniej do rejestru, bądź jako park kulturowy.

Park kulturowy może zostać utworzony („w celu ochrony krajobrazu kulturowego oraz zachowania wyróżniających się krajobrazowo terenów z zabytkami nieruchomymi charakterystycznymi dla miejscowej tradycji budowlanej i osadniczej") na podstawie uchwały rady gminy po zasięgnięciu opinii wojewódzkiego konserwatora zabytków (art. 16 ust. 1 u.o.z.o.z.). Uchwała tworząca park kulturowy powinna określać dokładne granice parku, sposób jego ochrony, a także zakazy i ograniczenia enumeratywnie określone w ustawie o ochronie zabytków (wyrok NSA z 7 grudnia 2007 r., sygn. akt II OSK 1487/07). W orzecznictwie sądowoadministracyjnym podkreśla się, że „skoro uchwała o utworzeniu parku kulturowego kształtuje sposób korzystania z nieruchomości, to oznacza, że 
kształtuje ona sposób wykonywania prawa własności, gdyż korzystanie z rzeczy jest jednym $z$ atrybutów prawa własności. W tym zakresie skutki uchwały o utworzeniu parku kulturowego są analogiczne do skutków uchwalenia miejscowego planu zagospodarowania przestrzennego. Oznacza to, że interes prawny, który może zostać naruszony uchwałą o utworzeniu parku kulturowego ma swoje źródło w normach prawa materialnego regulujących prawa rzeczowe, w tym z pewnością prawo własności nieruchomości. Na naruszenie interesu prawnego uchwałą w przedmiocie utworzenia parku kulturowego mogą powoływać się osoby, którym do nieruchomości objętej uchwałą przysługują prawa rzeczowe, czyli prawa należące do kategorii praw bezwzględnych, które wywierają skutek względem wszystkich innych podmiotów" (wyrok WSA w Krakowie z 26 kwietnia 2016 r., sygn. akt II SA/Kr 1427/15). Warto zaznaczyć, że właściciel działki ma - na podstawie art. 101 ustawy z dnia 8 marca 1990 r. o samorządzie gminnym (Dz. U. 2018, poz. 994, ze zm.) - legitymację do zaskarżenia do sądu administracyjnego takiej uchwały rady gminy, która ogranicza jego swobodę dysponowania działką i korzystania z niej, np. przez włączenie jej obszaru do parku kulturowego (wyrok WSA w Krakowie z 18 grudnia 2007 r., sygn. akt III SA/Kr 569/07, LEX nr 368095). Możliwości skorzystania z tego uprawnienia służy art. 16 ust. 1a u.o.z.o.z., zgodnie z którym rada gminy ogłasza w prasie miejscowej, przez obwieszczenie, a także w sposób zwyczajowo przyjęty o podjęciu prac nad utworzeniem parku kulturowego, określając formę, miejsce i termin składania wniosków dotyczących projektu uchwały o utworzeniu parku kulturowego, nie krótszy niż 21 dni od dnia ogłoszenia.

Także na zasadach ogólnych i w takim samym trybie zaskarżalny jest miejscowy plan zagospodarowania przestrzennego, w którym pomieszczone mogą być ustalenia dotyczące ochrony zabytków (art. 7 pkt 4 u.o.z.o.z.), jeżeli więc ustalenia planistyczne przewidują ochronę konserwatorską określonego obszaru, właściciel ma możliwość zakwestionowania stosownej uchwały rady gminy, o ile narusza ona jego prawny interes.

Za podstawową formę ochrony zabytków należy uznać wpis do rejestru zabytków, który wywołuje określone skutki prawne i nakłada na właściciela (użytkownika) zabytku wiele obowiązków i restrykcji. Przykładowo: właściciel ma obowiązek szczegółowego uzgadniania z konserwatorem sposobu zagospodarowania zabytku (w tym przestrzegania określonego programu prac konserwatorskich), wiele czynności wykonywanych przy zabytku czy jego otoczeniu wymaga uzyskania pozwolenia konserwatora (wydawanego w formie decyzji administracyjnej), wszelkie prace konserwatorskie, restauratorskie, badania czy roboty budowlane muszą być wykonywane pod kierunkiem osoby o szczególnych, ściśle określonych kwalifikacjach. Ponadto, w ramach nadzoru, konserwator może wydać decyzję nakazującą wstrzymanie prac budowlanych przy zabytku, może też zobowiązać właściciela do przywrócenia poprzedniego stanu zabytku, może również wydać decyzję nakazującą wykonanie określonych prac. W szczegól- 
nych okolicznościach konserwator może nakazać czasowe zajęcie obiektu, a nawet - zadecydować o przejęciu zabytku ruchomego bądź o wywłaszczeniu zabytku nieruchomego na rzecz Skarbu Państwa lub właściwej gminy.

Zakres obowiązków wynikający z wpisania nieruchomości do rejestru zabytków zbliżony jest do zakresu obowiązków wynikających z ujęcia do gminnej ewidencji nieruchomości. Różnica w traktowaniu zabytków ujętych w rejestrze i tych wskazanych w ewidencji ma na pewno wymiar proceduralny. Jak opisano wyżej, postępowanie o wpis do rejestru zabytków ma charakter „klasycznego”, dwuinstancyjnego postępowania administracyjnego (art. 9 u.o.z.o.z.), w którym właściciel ma status strony, zachowując pełnię praw procesowych, a postępowanie kończy się wydaniem decyzji, której prawidłowość podlega badaniu przez sąd administracyjny. W postępowaniu tym bada się m.in., czy „dana nieruchomość lub rzecz ruchoma, ich części lub zespoły, będące dziełem człowieka lub związane z jego działalnością, stanowią świadectwo minionej epoki bądź zdarzenia, których zachowanie leży w interesie społecznym ze względu na posiadaną wartość historyczną, artystyczną lub naukową" (art. 3 pkt 1 u.o.z.o.z.). Na skutek nowelizacji z 2010 r. stało się możliwe ujmowanie w gminnej ewidencji zabytków nieruchomości niefigurujących wcześniej w rejestrze zabytków (ani w ewidencji wojewódzkiej). Natomiast jedynym wymogiem stawianym przez art. 22 ust. 5 pkt 3 u.o.z.o.z. dla ujęcia takich nieruchomości w ewidencji jest „wyznaczenie” takiego zabytku przez wójta (burmistrza, prezydenta miasta), co powinno nastąpić „w porozumieniu” z wojewódzkim konserwatorem zabytków. Jednocześnie ustawa o ochronie zabytków i opiece nad zabytkami nie stawia żadnych szczególnych wymogów, których spełnienie warunkowałoby „wyznaczenie” danej nieruchomości przez właściwy organ do ujęcia w ewidencji, nie precyzuje, na czym konkretnie to „wyznaczenie” miałoby polegać, ani nie określa formy, w jakiej powinno nastąpić „porozumienie” między wymienionymi organami. Z chwilą osiągnięcia tego porozumienia następuje włączenie karty adresowej zabytku nieruchomego do gminnej ewidencji, przy czym włączenie to stanowi jedynie czynność materialno-techniczną.

Wydane na podstawie art. 24 ust. 1 u.o.z.o.z. rozporządzenie MKiDN powinno wskazywać przesłanki, od których spełnienia jest uzależnione włączenie kart ewidencyjnych i adresowych do ewidencji, a także ich wyłączenie z tych ewidencji (art. 24 ust. 4 u.o.z.o.z.). Ponadto rozporządzenie to powinno określać wzory m.in. gminnych kart ewidencyjnych oraz dane, jakie powinny być ujęte w karcie adresowej zabytku, a także sposób gromadzenia dotyczących go dokumentów $(\$ 3)$. Przepisem odnoszącym się do omawianej materii jest $\$ 18$ rozporządzenia MKiDN, określający „aspekty proceduralne” włączenia karty adresowej do gminnej ewidencji zabytków [„wójt (burmistrz, prezydent miasta) włącza kartę adresową zabytku nieruchomego do gminnej ewidencji zabytków po sprawdzeniu, czy dane zawarte w karcie adresowej są wyczerpujące i zgodne ze stanem faktycznym"]. Z kolei zakres informacji zawartych w karcie adresowej wyznacza 
$\$ 17$ rozporządzenia MKiDN: „karta adresowa zabytku nieruchomego zawiera następujące rubryki: nazwa, czas powstania, miejscowość, adres, przynależność administracyjna, formy ochrony, opracowanie karty adresowej, fotografia $\mathrm{z}$ opisem wskazującym orientację albo mapa z zaznaczonym stanowiskiem archeologicznym”. Wzór takiej karty określa załącznik nr 6 ( $\$ 17$ ust. 2 rozporządzenia). Przepisy te określają jedynie, jakiego rodzaju informacje gromadzi organ w celu dokonania wpisu do gminnej ewidencji zabytków i jaki jest zakres dostępnych informacji o walorach zabytkowych danego obiektu. Natomiast żaden z przepisów ustawy o ochronie zabytków i opieki nad zabytkami czy też rozporządzenia MKiDN nie przewiduje możliwości uczestnictwa zainteresowanego podmiotu (właściciela czy też użytkownika) w procesie włączania karty do gminnej ewidencji zabytków. Wskazany $\$ 18$ określa wyłącznie obowiązek organu, polegający na włączeniu karty adresowej zabytku nieruchomego do gminnej ewidencji zabytków po sprawdzeniu, czy dane zawarte w karcie są wyczerpujące i zgodne ze stanem faktycznym. Obowiązki organu ograniczone są zatem do nielicznych czynności technicznych związanych $\mathrm{z}$ badaniem treści karty adresowej zabytku. Warto wskazać, że zgodnie z orzecznictwem sądów administracyjnych, „opracowanie dla obiektu zabytkowego karty ewidencyjnej i dołączenie jej do prowadzonego zbioru, czyli włączenie do wojewódzkiej ewidencji zabytków, ma charakter czynności materialno-technicznej, a nie jest aktem administracyjnym przybierającym postać decyzji, postanowienia bądź zarządzenia" (wyrok WSA w Bydgoszczy z 6 lutego 2018 r., sygn. akt II SA/Bd 1060/16). Ustalenia powyższe można mutatis mutandis odnieść do gminnej ewidencji zabytków.

3. Jak wynika $z$ dotychczasowych ustaleń, w świetle obowiązujących przepisów ustawy o ochronie zabytków i opieki nad zabytkami właścicielowi nieruchomości, która ma zostać ujęta w gminnej ewidencji zabytków, nie przysługują uprawnienia strony postępowania administracyjnego. Na żadnym etapie sprawy włączenia karty adresowej właściciel nie może uczestniczyć w podejmowanych czynnościach. W szczególności pozbawiony jest on możliwości uczestniczenia w czynnościach dotyczących meritum sporu, czyli charakteru nieruchomości i zasadności włączenia karty adresowej do gminnej ewidencji nieruchomości. Również kontrola sądowoadministracyjna ma jedynie charakter formalny (wyroki NSA z: 21 maja 2015 r., sygn. II OSK 2189/13; 15 grudnia 2016 r., sygn. I OSK 713/15; postanowienie NSA z 14 września 2012 r., sygn. akt II OSK 1950/12; wyrok WSA w Łodzi z 5 września 2017 r., sygn. akt II SA/Łd 274/17). W szczególności żaden $\mathrm{z}$ organów nie prowadzi postępowania dowodowego w rozumieniu Kodeksu postępowania administracyjnego. Nie ma możliwości złożenia odpowiedniego wniosku dowodowego również na etapie podejmowania rozstrzygnięcia o ujęciu nieruchomości w gminnej ewidencji zabytków, gdyż postępowanie $\mathrm{w}$ tej sprawie nie ma charakteru postępowania administracyjnego, a jej rozstrzygnięcie - charakteru decyzji administracyjnej. Brak przepisów określających tryb postępowania skutkuje tym, że kontrola legalności działania 
organu sprowadza się w takiej sytuacji do badania zgodności tego działania jedynie z przepisami administracyjnego prawa materialnego: „Przepisy ustawy z dnia 23 lipca 2003 r. o ochronie zabytków i opiece nad zabytkami nie przewidują, by ujęcie zabytku przez prezydenta miasta w gminnej ewidencji zabytków stanowiło rozstrzygnięcie podejmowane przez organ gminy w formie decyzji administracyjnej. Konsekwencją tego zapatrywania jest odstąpienie od wymogu wydania rozstrzygnięcia w sprawie po przeprowadzeniu postępowania wyjaśniającego (dowodowego) w oparciu o zasady wynikające z kodeksu postępowania administracyjnego" (wyrok WSA w Łodzi z 5 września 2017 r., sygn. akt II SA/Łd 274/17). W konsekwencji w tak ukształtowanej procedurze właściciel nie jest, na żadnym etapie, poinformowany o działaniach podejmowanych przez organ administracji.

Kontrowersje budzi zatem zarówno tryb, jak i zakres ochrony udzielanej przez sąd administracyjny oraz przysługującej mu kognicji. W szczególności rozbieżności wywołuje podstawowa kwestia, czy do ewidencji gminnej wpisuje się nieruchomości o walorach zabytkowych, po stwierdzeniu spełnienia przez nie kryteriów materialnej definicji „zabytku” z art. 3 pkt 1 u.o.z.o.z. Z jednej strony wyrażone jest stanowisko, że posiadanie walorów zabytkowych nie może być z góry zakładane, lecz powinno być poprzedzone ekspertyzą i badaniami obiektu, który ma być ujęty w gminnej ewidencji (tak wyroki WSA w Warszawie z 3 lipca 2013 r. sygn. akt VII SA/Wa 2652/12 i VII SA/Wa 2652/13). Z drugiej strony w uzasadnieniu wyroku NSA z 2 kwietnia 2014 r., sygn. akt II OSK 2637, stwierdzono, że w sprawach o wpis do ewidencji gminnej sąd administracyjny bada jedynie, czy organ dokonał wskazanych w tym przepisie - symbolicznych - czynności: „Skoro przepis ten [ $\$ 18$ rozporządzenia MKiDN - dopisek A.T.] nie określa jakichkolwiek wymogów, ani też sformalizowanego trybu sprawdzenia zgodności danych, to nie można skutecznie czynić zarzutu naruszenia omawianego przepisu bez wykazania zaistnienia niezgodności danych zawartych w karcie adresowej ze stanem faktycznym. Skarżąca kasacyjnie faktu takiego nie wykazała, a ponadto jej wywody, co do powinności organu, któremu przypisała powinność przekazania do sprawdzenia przez uprawniony organ karty adresowej (przed włączeniem jej do gminnej ewidencji zabytku oraz odnotowania jej sprawdzenia), po pierwsze, nie precyzują, jaki organ, jakiemu podmiotowi i w jakim trybie winien przekazać ww. kartę do sprawdzenia, a po wtóre, nie wynikają ani z przepisu $\$ 18$ ww. rozporządzenia, ani też z jakiegokolwiek innego przepisu, który mógłby mieć zastosowanie w sprawie”. Podobnie w wyroku z 18 grudnia 2014 r. WSA w Łodzi, sygn. akt II SA/Łd 638/14, wskazał: „W ramach sprawy ze skargi na zarządzenie w sprawie przyjęcia do gminnej ewidencji danej nieruchomości nie można kwestionować jej zabytkowego charakteru, tj. oceny, czy dany obiekt odpowiada definicji zabytku z art. 3 pkt 1 ustawy o ochronie zabytków i opiece nad zabytkami. $Z$ art. 3 pkt 1 ustawy wynika, iż zabytkiem jest nieruchomość lub rzecz ruchoma, ich części lub zespoły, będące dziełem człowieka lub związa- 
ne z jego działalnością i stanowiące świadectwo minionej epoki bądź zdarzenia, których zachowanie leży w interesie społecznym ze względu na posiadaną wartość historyczną, artystyczną lub naukową. Ustalenie okoliczności wskazanych powyżej wymaga przeprowadzenia specjalistycznych ustaleń i ocen. Wymagań takich nie stawia jednak art. 22 ust. 5 ustawy o ochronie zabytków i opiece nad zabytkami. Przepis ten posługuje się już terminem zabytku, określając jednocześnie powinność m.in. wyznaczenia zabytku przez właściwy organ w porozumieniu z wojewódzkim konserwatorem zabytków. Wbrew twierdzeniom skarżącego organ nie przeprowadza w tym postępowaniu analizy stanu historycznego ani jakichkolwiek badań architektonicznych”. Warto także podkreślić brak „procedury wyłączenia” nieruchomości z ewidencji, której istnienie mogłoby w pewien sposób „łagodzič” ocenę regulacji. Co więcej, zmiana charakteru ewidencji gminnej dokonana nowelizacją z 2010 r. nastąpiła tylko na poziomie ustawowym i tylko częściowo, natomiast rozporządzenie MKiDN utrzymało inwentaryzacyjny charakter ewidencji, gdzie „karta adresowa” zawiera dane umożliwiające jedynie identyfikację danej nieruchomości, bez odniesienia do potencjalnych walorów zabytkowych. Jak trafnie podkreśla się w doktrynie, „ustawodawca rozszerzając zakres przedmiotowy gminnej ewidencji zabytków, nie uporządkował kwestii zasad, trybu i formy umieszczania poszczególnych obiektów w omawianym wykazie" (M. Karcz-Kaczmarek, Zaufanie do organów władzy publicznej w procedurze prowadzenia gminnej ewidencji zabytków [w: Sprawiedliwość i zaufanie do władz publicznych $w$ prawie administracyjnym, red. M. Kasiński, M. Stahl, K. Wlaźlak, Warszawa 2015, s. 898-899).

$\mathrm{W}$ aktualnym stanie prawnym wpis do ewidencji stanowi zatem, w rozumieniu regulacji konstytucyjnych, formę ograniczenia prawa własności. Wpisanie danej nieruchomości do ewidencji wprowadza elementy publicznoprawnego, formalnego nadzoru nad sposobem wykonywania prawa własności.

4. Trudno także uznać, że omawiana ingerencja w prawo własności jest konieczna w państwie demokratycznym dla realizacji takich wartości, jak porządek publiczny oraz ochrona wolności i praw innych osób (art. 31 ust. 3 Konstytucji). Zgodnie z wymogiem przydatności „prawodawca może ustanowić jedynie takie ograniczenia konstytucyjnych praw i wolności, które uzasadnione są racjonalną potrzebą ingerencji w danym stanie prawnym i faktycznym oraz służą bezpośrednio realizacji konstytucyjnie uzasadnionego celu. Cel ten wpisany jest w treść zasad konstytucyjnych" (wyrok TK z 25 maja 2016 r., sygn. akt Kp 2/15). Celem i treścią ustawy o ochronie zabytków i opieki nad zabytkami jest niewątpliwie ochrona dziedzictwa artystycznego, naukowego i historycznego, stanowiąca również wartości konstytucyjne (art. 5, art. 6, art. 73 Konstytucji). Również same ograniczenia są co do zasady dopuszczalne zarówno w celu ochrony szczególnej wolności innych osób, wymienionej w art. 73 Konstytucji, tj. wolności korzystania $\mathrm{z}$ dóbr kultury, jak i ze względu na ochronę porządku publicznego. Mimo bowiem tego, że zapewnienie skutecznej ochrony zabytków 
(dóbr kultury) nie zostało wymienione expresis verbis jako odrębna wartość konstytucyjna uzasadniająca ograniczenie konstytucyjnych wolności i praw obywateli, w orzecznictwie nie ulega najmniejszej wątpliwości, że ochrona zabytków mieści się w katalogu z art. 31 ust. 3 Konstytucji, stanowiąc składową pojęcia ochrony porządku publicznego (wyroki TK z: 8 października 2007 r., sygn. akt K 20/07; 25 maja 2016 r., sygn. akt Kp 2/15). Z tego założenia nie wynika jednak automatycznie, by równie racjonalne i uzasadnione było pozbawienie właścicieli nieruchomości zabytkowych ochrony prawnej, przede wszystkim poprzez odebranie gwarancji o charakterze proceduralnym.

Fakt, że objęcie ochroną akceptuje wyspecjalizowany organ (konserwator) oraz to, że sprawa może w ostateczności trafić do sądu administracyjnego - nie zmienia tej optyki. Trudno także uznać, by brak informacji odnośnie do prowadzonych działań skutkujących ograniczeniem własności służył realizacji konstytucyjnie uzasadnionych wartości. Przeciwnie, pozostaje w oczywistej sprzeczności z zasadą jawności (transparentności) działania władzy publicznej. Wyłączenie jawności czynności władczych może prowadzić także do nieprzewidywalności pozycji właścicieli takich nieruchomości. Brak odpowiednich gwarancji ochronnych grozi arbitralnością i dowolnością działań władzy.

Również w świetle orzecznictwa ETPC oczywiste jest, że procedury ochronne powinny zapewniać efektywne przedstawienie sprawy właściwym władzom oraz zapewniać skuteczne kwestionowanie działań ingerujących w gwarantowane prawa (Grande Stevens $i$ inni vs Włochy, wyrok z 4 marca 2014 r., skarga nr 18640/10 i inne, $\$ 188$ ). Państwa mają pozytywny obowiązek zapewnienia procedury oferującej konieczne gwarancje proceduralne i pozwalającej sądom krajowym rozpatrzyć rzetelnie i skutecznie wszelkie spory na tle własności (Sovtransavto Holding vs Ukraina, wyrok z 25 lipca 2002 r., skarga nr 48553/99, $\$$ 96; Bistrovic vs Chorwacja, wyrok z 31 maja 2007 r., skarga nr 25774/05, § 33; Anheuser-Busch Inc. vs Portugalia, wyrok Wielkiej Izby z 11 stycznia 2007 r., skarga nr 73049/01, \$83; Zehentner vs Austria, skarga nr 20082/02, wyrok z 16 lipca 2009 r., $\$ 75)$. Tym bardziej dotyczy to sytuacji, gdy samo państwo jest stroną takiego sporu z jednostką (Potomski i Potomska vs Polska, wyrok z 9 marca 2011 r., skarga nr 33949/05, \$74). Z art. 1 protokołu wywodzony jest pozytywny obowiązek państwa wprowadzenia odpowiednich mechanizmów sądowych dla skutecznego rozstrzygania sporów dotyczących własności oraz zapewnienia efektywnego wykonywania orzeczeń sądowych i administracyjnych. W przywołanej już sprawie Potomski i Potomska vs Polska Trybunał stwierdził naruszenie gwarancji konwencyjnych właśnie $\mathrm{z}$ tego powodu, że państwo nie zapewniło odpowiednich procedur ochronnych względem naruszonego prawa własności (umożliwienia wykupu nieruchomości bądź jej wywłaszczenia na wniosek właściciela, którego całkowicie pozbawiono możliwości korzystania ze swojej własności, ze względu na jej cenne walory zabytkowe). Innymi słowy, nawet jeżeli ingerencja $\mathrm{w}$ prawa majątkowe zmierzała do realizacji uprawnionego celu i leżała $\mathrm{w}$ intere- 
sie powszechnym w rozumieniu artykułu 1 protokołu nr 1 do Konwencji, kluczowe jest również zbadanie, czy znaleziono właściwą równowagę (proporcję) pomiędzy założonym celem a prawami skarżącego. Wymagane są więc określone gwarancje proceduralne chroniące przed arbitralnością i nieprzewidywalnością decyzji.

5. Powyższe wątpliwości są także podnoszone przez Rzecznika Praw Obywatelskich (który wielokrotnie formułował wobec znowelizowanych przepisów ustawy o ochronie zabytków i opieki nad zabytkami takie same zarzuty jak inicjator niniejszego postępowania) i Ministra Kultury i Dziedzictwa Narodowego - dostrzegającego potrzebę ingerencji mającą na celu wypełnienie luki prawnej i wprowadzenie przepisów służących wzmocnieniu ochrony praw właścicieli (użytkowników wieczystych) nieruchomości podlegających wpisaniu do gminnej ewidencji zabytków.

$\mathrm{Z}$ informacji dostępnej na stronie Ministerstwa Kultury i Dziedzictwa Narodowego w „wykazie prac legislacyjnych Ministra Kultury i Dziedzictwa Narodowego dotyczącego projektów rozporządzeń Ministra Kultury i Dziedzictwa Narodowego" (stan na dzień 24 stycznia 2019 r.) uwzględniono projekt rozporządzenia zmieniającego dotychczasowe rozporządzenie w sprawie prowadzenia rejestru zabytków, krajowej, wojewódzkiej i gminnej ewidencji zabytków oraz krajowego wykazu zabytków skradzionych lub wywiezionych za granicę niezgodnie z prawem („wstępne prace”). Jak wskazano w wykazie: „Proponowane zmiany zmierzają do poprawy standardu ochrony praw osób, którym przysługują określone prawa do zabytku włączanego do gminnej ewidencji zabytków. Nowelizacja jest odpowiedzią na wystąpienia Rzecznika Praw Obywatelskich, w których wskazuje on na potencjalną niezgodność $\$ 18 \mathrm{w}$ związku $\mathrm{z} \$ 17$ rozporządzenia z art. 64 ust. 1 i 2 w związku z art. 31 ust. 3 i z art. 2 Konstytucji Rzeczypospolitej Polskiej w zakresie, w jakim pozbawia właściciela nieruchomości podlegającej wpisowi do gminnej ewidencji zabytków gwarancji ochrony przed ograniczeniem jego prawa własności”. Zgodnie z założeniami istota zmian ma polegać na: „1) wprowadzeniu obowiązku zawiadamiania właściciela zabytku przez wojewódzkiego konserwatora zabytków o włączeniu zabytku do wojewódzkiej ewidencji zabytków oraz o wyłączeniu zabytku z ewidencji; 2) wprowadzeniu obowiązku zawiadamiania właściciela zabytku przez wójta (burmistrza, prezydenta miasta) o włączeniu zabytku do gminnej ewidencji zabytków oraz o wyłączeniu zabytku z ewidencji; 3 ) dodaniu przepisu określającego, że porozumienie organu prowadzącego gminną ewidencję zabytków z wojewódzkim konserwatorem zabytków, co do ujęcia w ewidencji zabytku, który nie jest wpisany do rejestru zabytków ani nie został włączony do wojewódzkiej ewidencji zabytków (przypadek, o którym mowa w art. 22 ust. 5 pkt 3 ustawy z dnia 23 lipca 2003 r. o ochronie zabytków i opiece nad zabytkami [...]) ma formę pisemną, a stanowisko wojewódzkiego konserwatora zabytków o zasadności włączenia zabytku do ewidencji wymaga szczegółowego uzasadnienia”. Planowany termin wydania 
rozporządzenia określono na I kwartał 2019 r. (http://bip.mkidn.gov.pl/media/ download_gallery/20190125_24_01_2019_BIP_WYKAZ_PRAC_LEGISLACYJNYCH_MKIDN_-_PROJEKTY_ROZPORZaDZEn.pdf).

Zmiana ta nie tylko wychodziłaby naprzeciw postulatom pytającego sądu, ale przede wszystkim mogłaby stanowić element szerszej nowelizacji ustawy o ochronie zabytków i opiece nad zabytkami, zmierzającej również do wykonania wyroku Europejskiego Trybunału Praw Człowieka z 29 marca 2011 r. w sprawie Potomska i Potomski vs Polska (nr skargi 33949/05).

6. Reasumując, należy uznać, że zakwestionowany art. 22 ust. 5 pkt 3 u.o.z.o.z. we wskazanym zakresie jest niezgodny $\mathrm{z}$ art. 64 ust. 1 i ust. $2 \mathrm{w}$ związku $\mathrm{z}$ art. 31 ust. 3 Konstytucji oraz $\mathrm{z}$ art. 1 protokołu nr 1 do Konwencji o ochronie praw człowieka i podstawowych wolności.

\section{Bibliografia}

Ginter A., Michalak A., Komentarz do art. 7 [w:] Ustawa o ochronie zabytków i opiece nad zabytkami. Komentarz, 2016, LEX nr 500561.

Karcz-Kaczmarek M., Zaufanie do organów władzy publicznej w procedurze prowadzenia gminnej ewidencji zabytków [w:] Sprawiedliwość i zaufanie do władz publicznych w prawie administracyjnym, red. M. Kasiński, M. Stahl, K. Wlaźlak, Warszawa 2015.

Tuleja P., Zaniechanie ustawodawcze [w:] Ustroje, doktryny, instytucje polityczne. Ksiega jubileuszowa Profesora zw. dra hab. Mariana Grzybowskiego, red. J. Czajowski, Kraków 2007.

Wróbel A. [w:] Konwencja o ochronie praw człowieka i podstawowych wolności. Komentarz do artykułów 19-59 oraz protokołów dodatkowych, t. II, red. L. Garlicki, Warszawa 2011. 